\title{
MUZAKKI DAN MUSTAHIQ
}

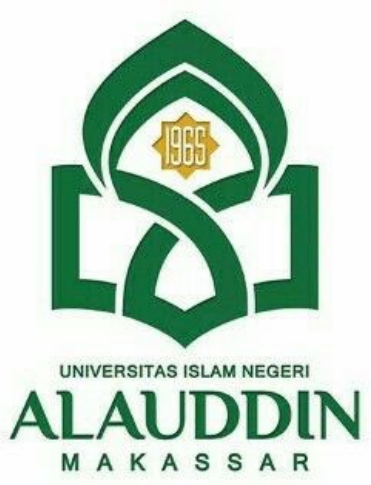

MAKALAH

Ditugaskan Pada Mata Kuliah Manajemen Zakat dan Wakaf Program Studi Perbankan Syariah Semester 5 Tahun 2021

Oleh:

\section{Kelas C}

Muhammad Zaifuddin 90500119075

Firdayanti F 90500119085

Urmila Az Zahra 90500119079

Dosen Pengajar:

Supriadi, SE.I, M.E.I

PROGRAM STUDI PERBANKAN SYARIAH

FAKULTAS EKONOMI DAN BISNIS ISLAM

UIN ALAUDDIN MAKASSAR

T.A 2021 


\section{KATA PENGANTAR}

\section{Bismillahirrahmanirrahim}

Assalamualaikum wr.wb

Puji syukur kehadirat Allah SWT yang telah memberikan rahmat dan hidayahNya sehingga kami dapat menyelesaikan tugas makalah yang berjudul “ $\boldsymbol{M U Z \boldsymbol { A } \boldsymbol { K } \boldsymbol { K } \boldsymbol { I }}$ DAN MUSTAHIQ" ini tepat pada waktunya. Tidak lupa pula shalawat serta salam senantiasa tercurahkan bagi Baginda Agung Rasulullah SAW yang syafaatnya akan kita nantikan kelak.

Adapun penulisan makalah berjudul “MUZAKKI DAN MUSTAHIQ" ini dibuat untuk memenuhi tugas mata kuliah Manajemen Zakat dan Wakaf

Dengan kerendahan hati, kami memohon maaf apabila ada ketidaksesuaian kalimat dan kesalahan dalam makalah ini. Kami menyadari, makalah yang kami susun ini masih jauh dari kata sempurna. Oleh karena itu, kritik dan saran yang membangun akan kami nantikan demi kesempurnaan makalah ini.

Akhir kata, semoga makalah ini bisa bermanfaat bagi kita semua dan menjadi sarana untuk menambah ilmu,wawasan serta pemahaman kita, Aamiin.

Wassalamu alaikum warahmatullahi wabarakatuh

Makassar, September 2021

$\underline{\text { Kelompok IV }}$ 


\section{DAFTAR ISI}

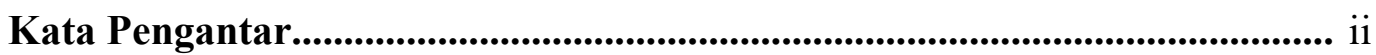

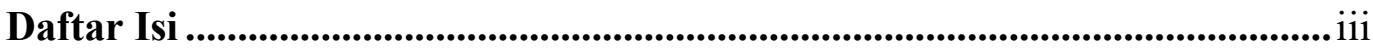

\section{BAB I PENDAHULUAN}

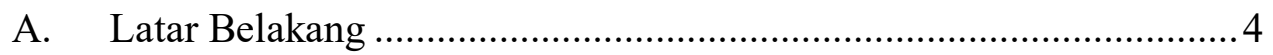

B. Rumusan Masalah ........................................................................ 4

C. Tujuan................................................................................. 5

\section{BAB II PEMBAHASAN}

A. Sejarah Singkat Kewajiban Zakat .................................................... 6

B. Pengertian Muzakki dan Syarat-Syaratnya ....................................... 8

C. Pengertian Mustahiq dan Syarat-Syaratnya ….................................... 10

D. Delapan Mustahiq Zakat dalam Konteks Indonesia......................... 12

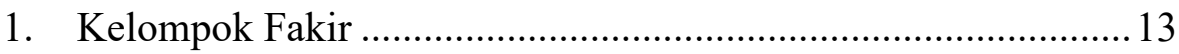

2. Kelompok Miskin.................................................................... 13

3. Kelompok Amil Zakat............................................................ 15

4. Kelompok Muallaf .................................................................. 16

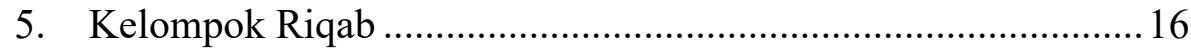

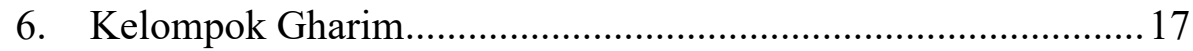

7. Kelompok Fi Sabilillah ......................................................... 18

8. Kelompok Ibnu Sabil ............................................................. 19

E. Membangun Basis Data Muzakki..................................................20

F. Komitmen Perusahaan Menjadi Muzakki..........................................23

\section{BAB III PENUTUP}

Kesimpulan.

\section{Daftar Pustaka}




\section{BAB I \\ PENDAHULUAN}

\section{A. Latar Belakang}

Muzakki dan mustahiq merupakan bagian dari unsur-unsur pokok pelaksanaan zakat. Keduanya memiliki kedudukan yang sangat penting mengingat tanpa adanya salah satu dari keduanya, maka zakat tidak dapat terlaksana. Oleh karena itu, keduanya memiliki peran, kewajiban dan hak yang saling melengkapi untuk menyeimbangkan kehidupan beragama maupun kehidupan sosial. Pembahasan muzakki dan mustahiq dalam bidang keilmuwan terus mengalami perkembangan seiring dengan perkembangan dunia yang semakin kompleks dan tak jarang menimbulkan beberapa pertanyaan sehingga perlu adanya diskusi untuk menjawab pertanyaan tersebut. Keadaan tersebut juga berlaku di Indonesia di mana negara Indonesia merupakan negara dengan mayoritas penduduknya beragama Islam.

Konsep muzakki dan mustahiq yang telah dikemukakan oleh para ulama dan Imam terdahulu harus berbenturan dengan realitas yang terjadi di Indonesia pada era modern saat ini. Terutama apabila dikaitkan dengan pengelolaan zakat yang akan dilakukan oleh pemerintah dalam mendistribusikan pendapatan zakat. Apakah pendapat dan ajaran yang telah dikemukakan dari hasil ijtihad yang berlandaskan al-Qur'an dan al-Hadits oleh para para ulama dan Imam terdahulu masih relevan pada kondisi Indonesia saat ini? Lalu, bagaimana kebijakan pemerintah dalam menyikapi hal ini? Atas dasar inilah, makalah ini akan membahas lebih lanjut mengenai muzakki dan mustahiq dalam koteks Indonesia.

\section{B. Rumusan Masalah}

a. Bagaimana sejarah singkat kewajiban zakat?

b. Apa yang dimaksud dengan muzakki zakat dan apa saja syaratnya?

c. Apa yang dimaksud dengan mustahiq zakat dan apa saja syaratnya?

d. Bagaimana kajian delapan golongan mustahiq zakat dalamkonteks Indonesia. 


\section{Tujuan}

a. Untuk mengetahui sejarah singkat kewajiban zakat;

b. Untuk mengetahui arti muzakki dan syarat-syaratnya;

c. Untuk mengetahui arti mustahiq dan syarat-syaratnya;

d. Untuk mengetahui delapan golongan mustahiq zakat dalam konteks Indonesia. 


\section{BAB II \\ PEMBAHASAN}

\section{A. Sejarah Singkat Kewajiban Zakat}

Pada awal kelahiran Islam di Mekkah, kewajiban zakat senantiasa disampaikan Allah SWT dengan ungkapan anfiqu fi sabilillah (berinfaklah kamu di jalan Allah SWT). Saat itu belum ditentukan jenis-jenis harta kekayaan yang wajib diinfakkan, demikian juga nisab dan persentase yang harus diserahkan untuk kepentingan $f i$ sabilillah. Tujuan infak pada saat itu adalah untuk menutupi hajat orang-orang miskin, dandana penyiaran agama Islam.

Pada saat al-Qur'an yang memerintahkan berinfak diturunkan, kaum muslimin pernah dua kali mengajukan pertanyaan tentang apa saja yang akan mereka infakkan dan berapa nilai atau kadar yang harus diinfakkan. Tetapi Allah SWT tetap saja tidak menentukan apa saja dan berapa saja yang mereka infakkan. Allah SWT menyerahkannya kepada hati nurani umat Islam untuk mengaplikasikan rasa syukur terhadap nikmat dan keimanan kepada Allah SWT. Allah SWT hanya memberi batasan bahwa yang diinfakkan itu adalah yang melebihi dari kebutuhan, seperti firman Allah SWT dalam ayat 219 surat al-Baqarah:

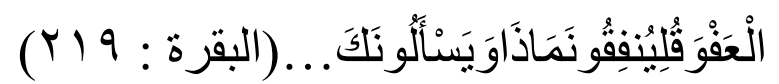

"Dan mereka bertanya kepadanya tentang apa yang mereka nafkahkan. Katakanlah: "Yang kebih dari keperluan..." (QS. Al-Baqarah: 219)1 Tentang kepada siapa infak itu diserahkan, Allah SWT menerangkannya sebagaimana pada ayat 215 surat al-Baqarah:

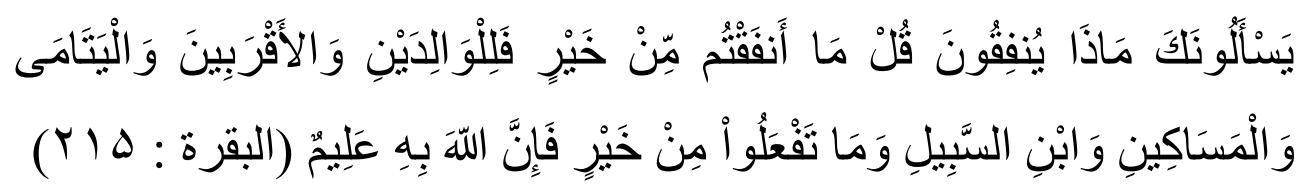

\footnotetext{
${ }^{1}$ Rahman Ritonga dan Zainuddin, Fiqh Ibadah, (Jakarta: Gaya Media Pratama, 2002), hal.173
} 
"Mereka bertanya kepadamu tentang apa yang mereka nafkahkan. Jawablah: "Apa saja harta yang kamu nafkahkan hendaklah diberikan kepada ibu bapak, kaum kerabat, anak-anak yatim, orang-orang miskin dan orang-orang yang sedang dalam perjalanan. Dan apa saja kebajikan yang dibuat, maka sesungguhnya Allah Maha Mengetahui." (QS. Al-Baqarah: 215)

Demikianlah al-Qur'an memerintahkan kewajiban zakat dengan ungkapan kata nafaqa tanpa memberi batasan tentang jenis harta dan kadar yang dinafkahkan. Hal ini berlangsung sampai tahun pertama setelah Nabi bersama umatnya hijrah ke Madinah. Hal ini dapat dipahami karena umat Islam saat itu belum siap menerima kewajiban yang beraspek sosial yang dibatasi dengan ketentuan-ketentuan yang mengikat. Oleh karena itu, kepada mereka diberi kebebasan apa saja dan berapa kadar yang mereka nafkahkan.

Pada tahun kedua hijriyah, baru Allah SWT memerintahkan kewajiban zakat dengan menggunakan ungkapan atu al-zakat (tunaikanlah zakat). Seiring dengan perintah itu Nabi SAW memberikan penjelasan mengenai ketentuan-ketentuannya, seperti jenis harta yang dikenakan wajib zakat, kadar nisab, dan persentasenya. Jadi sebenarnya pensyariatan zakat di Madinah merupakan pembaharuan terhadap perintah zakat yang diturunkan di Mekkah dengan ungkapan infaq.

Ketentuan zakat tersebut ditetapkan karena umat Islam saat itu sudah berbeda dengan ketika mereka di Mekah. Di Madinah mereka telah memiliki iman yang terkonsentrasi dan wilayah kehidupan mereka pun menjadi luas. Mereka telah membangun suatu masyarakat yang memiliki sistem kehidupan dan tujuan yang ingin dicapai di samping kondisi mereka yang telah memungkinkan menerima ketentuan dan batasan zakat. Puncak dari pensyariatan zakat adalah menetapkan atau mengumumkannya sebagai salah satu rukun Islam oleh Nabi SAW berdasarkan pada ayat 11 surat at-Taubah:

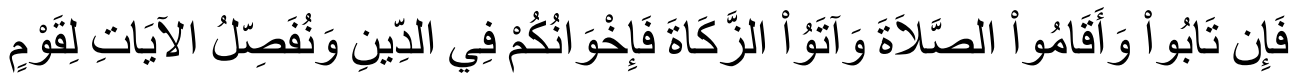
بَعْلَمَونَ (الَّوبه: (1) 
"Dan jika mereka bertobat, melaksanakan shalat dan menunaikan zakat, maka (berarti mereka itu) adalah saudara-saudaramu seagama. Kami menjelaskan ayat-ayat itu bagi orang-orang yang mengetahui.” (QS. AtTaubah: 11)

\section{B. Pengertian Muzakki dan Syarat-Syaratnya}

Muzakki adalah seseorang yang berkewajiban mengeluarkan zakat. ${ }^{2}$ Menurut Undang-Undang No. 38 Tahun 1999 tentang Pengelolaan Zakat pasal 1, muzakki adalah orang atau badan yang dimiliki oleh orang muslim yang berkewajiban menunaikan zakat. ${ }^{3}$ Zakat hanyalah diwajibkan atas orang yang telah memenuhi syarat-syarat sebagai berikut:

1. Islam

Dalil yang mendasarinya adalah perkataan Abu Bakar r.a:

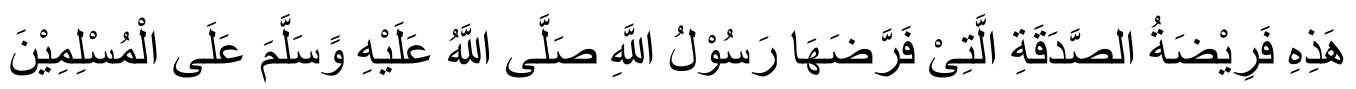

"Inilah kewajiban zakat yang telah ditetapkan oleh Rasulullah SAW atas kaum muslimin." (Riwayat al-Bukhari: 1386)

Dengan adanya kata-kata "atas kaum muslimin", berarti jelas bahwa selain orang Islam tidak dituntut mengeluarkan zakat. ${ }^{4}$

Seorang Islam yang telah memenuhi syarat wajib zakat kemudian ia murtad sebelum membayarkan zakatnya maka menurut fuqaha Syafi' 'iyah, wajib baginya mengeluarkan zakat yang dimilikinya sebelum murtad. Sedangkan Abu Hanifah berpendapat, murtadnya seseorang menggugurkan semua kewajibannya sebelum murtad, sebab setelah murtad ia sudah menjadi kafir asli dalam pengertian semua amal ibadahnya yang lalu tidak ada gunanya. ${ }^{5}$

\footnotetext{
${ }^{2}$ Umrotul Khasanah, Manajemen Zakat Modern: Instrumen Pemberdayaan Ekonomi Umat (Malang: UIN-Maliki Press, 2010), hal. 37

${ }^{3}$ Kementerian Agama, "UU No. 38 Tahun 1999 tentang Pengelolaan Zakat”, http://kemenag.go.id, diakses pada Sabtu, 12 September 2015, 12:23 WIB

${ }^{4}$ Anshory Umar Sitanggal, Fiqh Syafi'i Sistimatis II (Semarang: CV. Asy Syifa', 1987) hal. 13

${ }^{5}$ Rahman Ritonga dan Zainuddin, Fiqh Ibadah, (Jakarta: Gaya Media Pratama, 2002), hal.178
} 


\section{Merdeka}

Keharusan merdeka bagi wajib zakat menafikan kewajiban zakat terhadap hamba sahaya. Hal ini sebagai konsekuensi dari ketiadaan hak milik yang diberikan kepadanya. Hamba sahaya dan semua yang ada padanya menjadi milik tuannya. Demikian halnya hamba sahaya yang telah diberikan kesempatan untuk memerdekakan dirinya dengan tebusan, karena ini belum secara sempurna memiliki apa yang ada padanya.

3. Baligh dan berakal sehat

Ahli fiqh mazhab Hanafi menetapkan baligh dan berakal sebagai syarat wajib zakat. Menurut mereka, harta anak kecil dan orang gila tidak dikenakan wajib zakat karena keduanya tidak dituntut membayarkan zakat hartanya seperti halnya shalat dan puasa. Mayoritas ahli fiqh selain Hanafiyah tidak menetapkan baligh dan berakal sebagai syarat wajib zakat. Oleh karena itu, menurut mereka harta anak kecil dan orang gila wajib dikeluarkan zakatnya, dan yang mengeluarkannya adalah walinya, berdasarkan hadits Nabi SAW berikut:

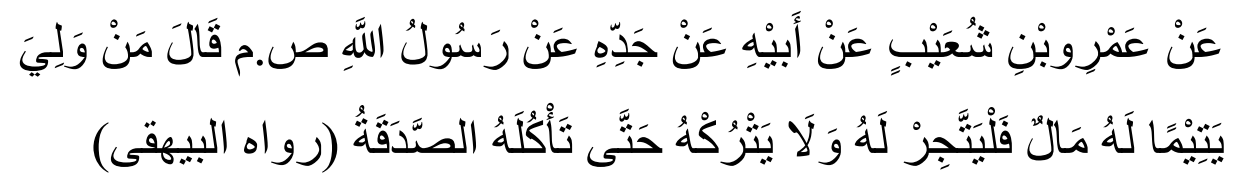

Dari 'Amr bin Syu'aib, dari bapaknya, dari neneknya, sesungguhnya Rasulullah SAW bersabda: "Siapa yang menjadi wali anak yatim yang memiliki harta hendaklah dia memperdagangkannya (mengembangkannya) dan dia tidak boleh meninggalkannya sampai harta itu termakan oleh zakat.” (HR. Baihaqi)

4. Memiliki harta atau kekayaan yang cukup nisab

Orang tersebut memiliki sejumlah harta yang telah cukup jumlahnya untuk dikeluarkan zakatnya.

5. Memiliki harta atau kekayaan yang sudah memenuhi haul 
Harta atau kekayaan yang dimiliki telah cukup waktu untuk mengeluarkan zakat yang biasanya kekayaan itu telah dimilikinya dalam waktu satu tahun.

6. Memiliki harta secara sempurna

Maksudnya adalah bahwa orang tersebut memiliki harta yang tidak ada di dalamnya hak orang lain yang wajib dibayarkan. Atas dasar syarat ini, seseorang yang memiliki harta yang cukup satu nisab, tetapi karena ia masih mempunyai hutang pada orang lain yang jika dibayarkan sisa hartanya tidak lagi mencapai satu nisab, maka dalam hal ini tidak wajib zakat padanya; karena hartanya bukanlah miliknya secara sempurna. Orang tersebut tidak dapat disebut orang kaya melainkan orang miskin. ${ }^{6}$

7. Muzakki adalah orang yang berkecukupan atau kaya

Zakat itu wajib atas si kaya yaitu orangyang mempunyai kelebihan dari kebutuhan-kebutuhan yang vital bagi seseorang, seperti untuk makan, pakaian, dan tempat tinggal. Zakat tersebut dibagikan kepada fakir miskin atau orang yang berhak menerima zakat. Hal ini berdasarkan sabda Rasulullah SAW.:

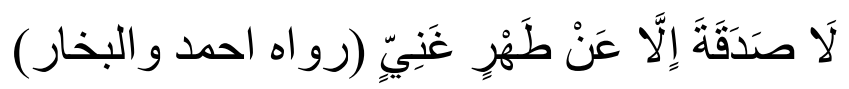

"Tidak wajib zakat kecuali dari pihak si kaya."7(HR. Ahmad dan Bukhari)

\section{Pengertian Mustahiq dan Syarat-syaratnya}

Menurut Undang-Undang No. 38 Tahun 1999 tentang Pengelolaan Zakat pasal 1, mustahiq adalah orang atau badan yang berhak menerima zakat. Para fuqaha menetapkan lima syarat atas orang yang berhak menerima zakat sebagai berikut ${ }^{8}$ :

1. Kefakiran atau kekurangan pemenuhan kebutuhannya

\footnotetext{
${ }^{6}$ Rahman Ritonga dan Zainuddin, Fiqh Ibadah, (Jakarta: Gaya Media Pratama, 2002), hal.179 ${ }^{7}$ Slamet Abidin dan Suyono, Fiqih Ibadah (Bandung: Pustaka Setia, 1998), hal. 196

${ }^{8}$ Wahbah Al-Zuhayly, Zakat: Kajian Berbagai Mazhab (Bandung: PT Remaja Rosdakarya, 2008), hal. 294-308
} 
Kefakiran adalah keadaan ekonomi seseorang yang serba kekurangan atau yang benar-benar membutuhkan. Kefakiran merupakan syarat umum atas semua zakat wajib dan sedekah. Oleh karena itu, zakat dan sedekah tidak boleh diberikan kepada orang kaya karena Nabi SAW pernah bersabda,

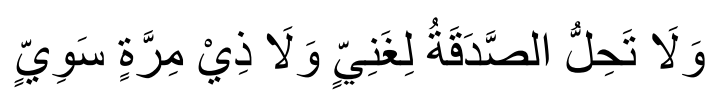

"Zakat tidak dihalalkan untuk orang kaya dan orang yang memiliki kekuatan dan kesempurnaan anggota tubuh."

2. Penerima zakat harus muslim

Orang yang menerima zakat dipersyaratkan harus orang Muslim, kecuali orang-orang yang baru masuk Islam. Menurut mazhab Maliki dan Hambali, zakat tidak boleh diberikan kepada orang kafir, apa pun alasannya; berasarkan hadits Mu'adz r.a.

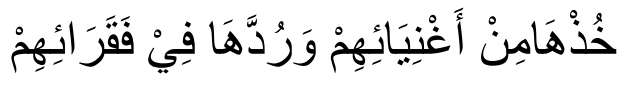

"Ambillah zakat dari orang-orang kaya dari mereka (Muslim) dan berikan kepada orang-orang fakir dari mereka (muslim)."

Abu Hanifah dan Muhammad berpendapat boleh, berdasarkan firman Allah SWT surat al-Baqarah ayat 271 di mana menurut mereka penjelasan ayat ini masih sangat umum. Dalam hal ini menurut mereka tidak boleh membeda-bedakan antara orang miskin yang satu dengan yang lainnya, kecuali orang-orang al-harbiy dengan alasan bahwa bila kita memberikan sedekah itu kepada mereka, berarti kita membantu mereka untuk memerangi kita.

Abu Yusuf, Zafar, Syafi'i, dan jumhur menyatakan, "Kita tidak boleh memberikan sedekah di luar zakat kepada orang-orang dzimmiy dan orang-orang harbiy, jika dikiaskan dengan zakat."

3. Penerima zakat bukan berasal dari keturunan Bani Hasyim Keturunan Bangi Hasyim (Ahl al-Bayt) diharamkan menerima zakat. Mereka diperbolehkan mengambil khumus dari Baitul Mal untuk mencukupi kebutuhan mereka berdasarkan sabda Nabi SAW, 


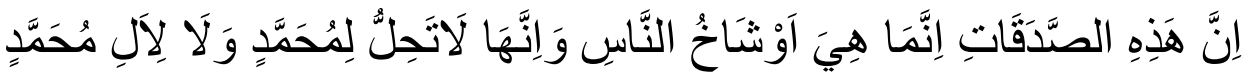

"Sesungguhnya zakat-zakat itu adalah kotoran manusia. Dia tidak dihalalkan untuk Muhammad dan juga tidak dihalalkan untuk keluarga Muhammad."

4. Penerima zakat bukan orang yang lazim diberi nafkah

Zakat tidak boleh diberikan kepada karib kerabat dan istri walaupun berada pada masa 'iddah, karena tindakan seperti ini akan menghalangi pemberian kepada orang fakir dari satu segi, dan dari segi yang lain zakat itu akan kembali kepada dirinya sendiri.

5. Penerima zakat akil dan baligh

Menurut mazhab Hanafi, zakat tidak boleh diterima oleh anak kecil yang umurnya belum tujuh tahun dan tidak boleh diterima oleh orang gila, kecuali bila anak kecil dan orang gila itu ada yang mengasuhnya. Mazhab Syafi'i mempersyaratkan bahwa orang yang menerima zakat itu hendaknya yang sudah baligh, akil dan waras pikirannya. Oleh karena itu, zakat tidak boleh diberikan kepada anak kecil, orang gila, orang yang kurang waras pikirannya, kecuali jika orang-orang itu ada yang mengasuhnya.

\section{Delapan Golongan Mustahiq Zakat dalam Konteks Indonesia}

Allah SWT telah menentukan golongan-golongan tertentu yang berhak menerima zakat, dan bukan diserahkan kepada pemerintah untuk membagikannya sesuai kehendaknya. Oleh karena itu, zakat harus dibagikan kepada golongan-golongan yang telah ditentukan yakni seperti dalam surat at-Taubah ayat 60 sebagai berikut:

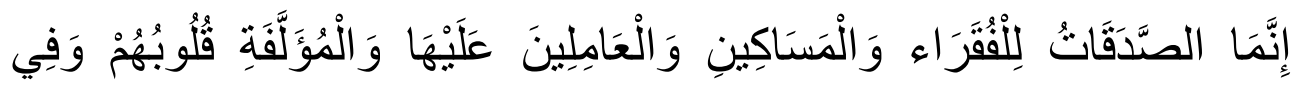

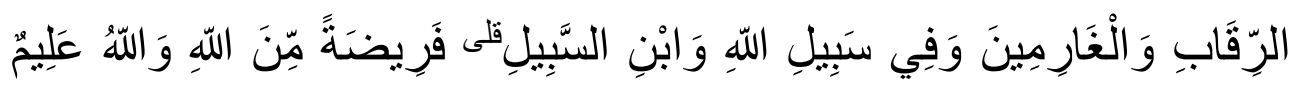

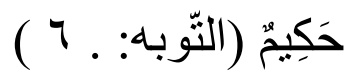

"Sesungguhnya zakat-zakat itu hanyalah untuk orang-orang fakir, orangorang miskin, para pengurus zakat, para mu'allafyangdibujuk hatinya, untuk 
(memerdekakan) budak, orang-orang yang berhutang untuk jalan Allah dan orang yang sedang dalam perjalanan, sebagai suatu ketetapan yang diwajibkan Allah. Dan Allah Maha Mengetahui lagi Maha Bijaksana." (Q.S. At-Taubah: 60)

Ayat di atas menunjukkan bahwa orang yang berhak menerima zakat terdiri dari delapan golongan. Berikut ini adalah penjelasan delapan golongan yang dimaksud tersebut sekaligus mengkajinya untuk menyesuaikan atau paling tidak, mewarnainya dengan kondisi Indonesia9

\section{Kelompok Fakir}

Termasuk dalam kelompok ini adalah orang yang tidak berharta dan tidak tercukupi makanan, pakaian maupun tempat tinggalnya, tidak mempunyai pekerjaan yang dapat memenuhi kebutuhan pokoknya.

\section{Kelompok Miskin}

Artinya orang yang masih memiliki sesuatu untuk menutupi hajatnya, tetapi tidak cukup. ${ }^{10}$ Dalam buku-buku Turasts (manuskrip), para ulama mazhab atau buku-buku kajian fikih kontemporer, secara umum pengertian yang dipaparkan oleh para ulama untuk fakir dan miskin tidak jauh dari indikator ketidakmampuannya secara materi untuk memenuhi kebutuhannya. Dengan demikian, indikator utama yang ditekankan para imam mazhab adalah a) ketidakmampuan pemenuhan kebutuhan materi; b) ketidakmampuan dalam mencari nafkah. Kelompok fakir dikaitkan dengan kenihilan materi sedangkan kelompok miskin dikaitkan dengan penghasilan yang tidak mencukupi.

Untuk membahas mengenai pengertian dan indikator kemiskinan di Indonesia, dapat dilihat dari model pemetaan dan pengukuran kemiskinan yaitu antara lain:

a. Model tingkat konsumsi

Model ini diarahkan pada pemenuhan kebutuhan pokok, dalam hal ini terutama beras. BPS mengartikan kemiskinan sebagai ketidakmampuan

${ }^{9}$ M. Arif Mufraini, Akuntansi dan Manajemen Zakat (Jakarta: Kencana, 2006), hal. 177-206

${ }^{10}$ Anshory Umar Sitanggal, Fiqh Syafi'i Sistimatis II (Semarang: CV. Asy Syifa', 1987) hal. 65 
untuk memenuhi standar minimum kebutuhan dasar yang meliputi kebutuhan makanan maupun nonmakanan.

b. Model kesejahteraan keluarga

Model ini dikembangkan oleh BKKBN untuk memetakan tahapan keluarga sejahtera. Sangat miskin (fakir) diartikan sebagai ketidakmampuan memenuhi kebutuhan dasarnya secara minimal seperti kebutuhan akan pengajaran agama, pangan, sandang, papan dan kesehatan. Dengan indikator belum dapat memenuhi salah satu atau lebih indikator berikut:

- Indikator ekonomi: makan dua kali atau lebih sehari; memiliki pakaian yang berbeda untuk aktivitas (misalnya di rumah, bekerja/sekolah, dan bepergian); bagian terluas lantai rumah bukan dari tanah

- Indikator non-ekonomi: melaksanakan ibadah; bila anak sakit dibawa ke sarana kesehatan.

Miskin diartikan sebagai keluarga yang mampu memenuhi kebutuhan sosial psikologisnya. Yang dimaksud kebutuhan sosial psikologis adalah kebutuhan akan pendidikan, keluarga berencana, interaksi dalam keluarga, interaksi dalam lingkungan tempat tinggal, dan transportasi. Indikatornya:

- Indikator ekonomi: paling kurang sekali seminggu keluarga makan daging atau ikan atau telur; setahun terakhir seluruh anggota keluarga memperoleh paling kurang satu pasang pakaian baru; dan luas lantai rumah paling kurang $8 \mathrm{~m}^{2}$ untuk tiap penghuni.

- Indikator non-ekonomi: ibadah teratur, sehat tiga bulan terakhir, punya penghasilan tetap, usia 10-60 tahun dapat baca tulis huruf latin, usia 6-15 tahun bersekolah; dan anak lebih dari 2 orang, berKB.

c. Model pembangunan manusia

Human Development Report (HDR) adalah satu konsep yang melihat pembangunan secara lebih komprehensif, di mana pembangunan harus 
menjadikan kesejahteraan manusia sebagai tujuan akhir, bukan hanya menjadikan manusia sebagai alat pembangunan. Di dalam konsep ini, juga dijelaskan bahwa pembangunan manusia pada dasarnya adalah memperluas antara pilihan-pilihan bagi masyarakat. Hal yang paling penting di antara pilihan-pilihan yang luas tersebut adalah hidup yang panjang dan sehat, untuk mendapatkan pendidikan dan memiliki akses kepada sumber daya untuk mendapatkan standar hidup yang layak.

\section{Kelompok Amil Zakat}

Menurut Fatwa Majelis Ulama Indonesia (MUI) No. 8 Tahun 2011 tentang amil zakat, pengertian amil zakat adalah seseorang atau sekelompok orang yang diangkat oleh pemerintah untuk mengelola pelaksanaan ibadah zakat; atau seseorang atau sekelompok orang yang dibentuk oleh masyarakat dan disahkan oleh pemerintah untuk mengelola pelaksanaan ibadah zakat. ${ }^{11}$ Dalam upaya optimalisasi sistem zakat sebagai salah satu proses redistribusi income, posisi amil dalam kelompok delapan ashnaf memiliki peranan yang sangat penting.

Gaji para petugas pengumpulan zakat (amil) dihitung berdasarkan kemampuan dan kadar kerjanya, pada umumnya berdasarkan persentase dari jumlah harta yang terkumpul seperti yang dikatakan Imam Syafi'i r.a. "Berikanlah kepada mereka jumlah tertentu, di mana jumlah ini pada zaman Umar bin Abdul Aziz mencapai 3\%”. Gaji tersebut wajib diberikan kepada para amil zakat meskipun mereka termasuk orang yang kaya dengan maksud untuk memberikan dorongan kepada mereka untuk bekerja dan berhemat dalam mengeluarkan biaya pengumpulam zakat. ${ }^{12}$

\section{Kelompok Muallaf}

Secara prinsip, pengertian muallaf adalah orang-orang yang baru memeluk agama Islam. Para ahli fikih banyak memberikan masukan antara lain yang menambah perluasan makna dari pengertian muallaf itu sendiri. Dalam kajian fikih klasik, muallaf diklasifikan menjadi empat

${ }^{11}$ Majelis Ulama Indonesia, Himpunan Fatwa MUI Sejak 1975 (Jakarta: Erlangga, 2011), hal. 271

12 M. Arif Mufraini, Akuntansi dan Manajemen Zakat (Jakarta: Kencana, 2006), hal. 186 
macam yaitu: Pertama, muallaf muslim ialah orang yang sudah masuk Islam tetapi niat dan imannya masih lemah. Kedua, orang yang telah masuk Islam, niat dan imannya sudah cukup kuat, dan juga terkemuka (tokoh) di kalangan kaumnya. Ketiga, muallaf yang mempunyai kemampuan untuk mengantisipasi tindak kejahatan yang datang dari kaum kafir. Keempat, muallaf yang mempunyai kemampuan mengantisipasi kejahatan yang datang dari kelompok pembangkang wajib zakat.

Zakat secara tidak langsung dapat menjadi alat daya tarik yang menstimultan nonmuslim untuk masuk Islam atau menstimultan orang Islam untuk lebih beriman dan menjauh dari tindak kriminal. Tidak hanya itu, pencerahan distribusinya dapat diarahkan kepada daerah atau tempat di mana orang Islam adalah minoritas, termarginalkan atau berbatasan dengan daerah musuh.

\section{Kelompok Riqab}

Dalam kajian fikih klasik yang dimaksud dengan para budak adalah perjanjian seorang muslim untuk bekerja dan mengabdi kepada majikannya, di mana pengabdian tersebut dapat dibebaskan apabila si budak memenuhi kewajiban pembayaran sejumlah uang, namun si budak tersebut tidak memiliki kemampuan materi untuk membayar tebusan atas dirinya tersebut. Bila melihat konsep tersebut, maka definisi tersebut sepintas tidak lagi bisa dipakai atau diterapkan pada kondisi sekarang, sehubungan dengan adanya pelarangan secara syariat dan bahkan konteks sekarang sudah menjadi isu pelarangan dalam skala internasional.

Penafsiran riqab mulai dari budak, bangsa terjajah, dan karyawan/buruh pada dasarnya berporos pada adanya kekuasaan satu pihak terhadap pihak lain, dalam hal ini yang menjadi pengait antara keduanya adalah kondisi perekonomian, di mana yang satu surplus dan yang lain defisit. Selanjutnya untuk kajian keindonesiaan, Arif Mufraini menyatakan ada sekelompok pekerja/buruh yang hampir mirip dengan 
kondisi riqab di masa era kenabian dan mirip dengan kelompok orang yang terjajah, namun tidak bisa dikatakan dengan sebagai pekerja atau buruh yang layaknya karyawan perusahaan atau pegawai negeri atau profesional tertentu, yaitu pembantu rumah tangga, kelompok pekerja atau buruh yang bertugas sebagai pembantu urusan dan pekerjaan rumah tangga orang, di dalam maupun luar negeri. ${ }^{13}$

\section{Kelompok Gharim}

Menurut mazhab Abu Hanifah, gharim adalah orang yang mempunyai utang dan aset yang dimiliki tidak mencukupi untuk memenuhi utangnya tersebut. Sedangkan Imam Maliki, Syafi'i, dan Ahmad menyatakan bahwa orang yang mempunyai utang terbagi kepada dua golongan, yaitu Pertama, kelompok orang yang mempunyai utang untuk kebaikan dan kemaslahatan diri dan keluarganya. Misalkan untuk membiayai dirinya atau keluarganya yang sakit, atau untuk membiayai pendidikan anaknya. Kedua, kelompok orang yang berutang untuk kemashlatahan orang atau pihak lain. Misalkan, orang yang terpaksa utang karena mendamaikan dua pihak atau dua orang yang sedang bertengkar, sedangkan untuk penyelesaiannya membutuhkan dana yang cukup besar. Atau kelompok orang yang menjalankan misi kemanusiaan, yang terpaksa berutang untuk memenuhi kebutuhan misi kelembagaan tersebut. Misalkan, yayasan sosial yang memelihara anak yatim, orangorang lanjut usia (panti jompo), orang-orang fakir, panitia pembangunan masjid, sekolah, perpustakaan, pondok pesantren dan lain-lain.

Dari beberapa pengertian di atas, untuk penerapannya di Indonesia, Lembaga Amil Zakat (LAZ)akan sangat mungkin menemukan kesulitan menyalurkan dana untuk kategori ini. Pengertian kondisi gharim akan sangat lekat dan berkaitan dengan kondisi kemiskinan dan kefakiran, sedangkan kelompok fakir dan miskin sudah ada jatahnya. Pada umumnya alasan orang berutang dapat diindikasikan untuk kepentingan

${ }^{13}$ M. Arif Mufraini, Akuntansi dan Manajemen Zakat (Jakarta: Kencana, 2006), hal. 196 
konsumtif maupun produktif. Utang konsumtif adalah utang yang diperuntukkan bagi kepentingan-kepentingan memenuhi kebutuhan sehari-hari. Sedangkan utang produktif adalah utang yang diperuntukkan untuk kepentingan menjalankan usaha, permodalan, menambah faktor produksi dan pembelian investasi dan lain sebaginya.

Motif konsumtif sebagaimana di atas, menurut Arif Mufraini sangat tepat untuk dikategorikan sebagai kelompok gharim namun untuk motif produktif masih perlu diadakan kajian mendalam.

\section{Kelompok Fi Sabilillah}

Sabilillah kerap diartikan sebagai jihad (berperang), karena memang pada sejumlah ayat al-Qur'an arti kata fi sabilillah sangat berdekatan dengan pemahaman jihad berperang di jalan Allah. Namun demikian, apabila ditelaah lebih dalam, memahami kata $f i$ sabilillah ternyata lebih luas dari pengertian berperang di jalan Allah. Tiap mazhab yang ada juga mengartikan $f i$ sabilillah dengan pengertian yang berbeda. Salah satunya adalah mazhab Syafi'i yang menyatakan bahwa sabilillah itu adalah sukarelawan di medan perang yang tidak mendapat tunjangan tetap dari pemerintah. Meskipun demikian, pengertian tersebut pun tidak perlu dibatasi hanya karena jihad fisik militer. Kadang-kadang, jihad pun dilakukan oleh lidah atau pena, sebagaimana yang dilakukan pedang dan tombak. $^{14}$

Bagian untuk sabilillah diberikan kepada para angkatan perang yang tidak mendapat gaji dari pemerintah. Tetapi menurut Imam Ahmad bin Hanbal, bagian zakat untuk sabilillah bisa di-tasharruf-kan (dugunakan) untuk membangun madrasah, masjid, jembatan, dan sarana umum lainnya. Agar zakat berdaya guna dan tepat guna, kita perlu mengambil pengertian "sabilillah" dalam makna yang luas, tidak membatasi pada pengertian berperang saja. Kalau kita sepakat mengambil pengertian

${ }^{14}$ Yusuf Qardhawi, Problematika Islam Masa Kini: Qardhawi Menjawab (Bandung: Trigenda Karya, 1995), hal. 331 
yang luas, maka segala hal yang berkaitan dengan maslahat umum termasuk dalam kategori sabilillah. ${ }^{15}$

Apabila dikaitkan dengan Indonesia sekarang yang tidak dalam kondisi berperang dengan pihak mana pun, maka tentu dana ini harus dialihkan kepada bentuk lain dari berjihad di jalan Allah. Bukan mereka yang mengangkat senjata api tapi bagi mereka yang mengangkat pena, menuntut ilmu untuk mengibarkan panji agama Allah di muka bumi ini. Perjuangan seorang muslim untuk meningkatkan SDM lebih realistis untuk dikatakan sebagai pejuang di jalan Allah untuk era ini. Masih banyak putra putri bangsa ini yang tidak sekolah atau putus sekolah karena kendala biaya. Dan masih banyak komunitas umat Islam di Indonesia yang membutuhkan sarana dan prasarana yang memadai dalam menyelenggarakan pendidikan.

\section{Kelompok Ibnu Sabil}

Ibnu sabil menurut jumhur ulama adalah kiasan untuk musafir (perantau), yaitu orang yang melakukan perjalanan dari satu daerah ke daerah lain. Imam Thabari meriwayatkan dari Mujahid: "Ibnu sabil mempunyai hak dari dana zakat apabila kehabisan akomodasi dan perbekalannya walaupun pada asal ekonominya berkecukupan."

Dalam kemajuan tekonologi informasi saat ini, memang kondisi ibnu sabil yang diilustrasikan pada artian klasik tampaknya sudah sangat kecil terjadi kemungkinannya. Apabila kondisi tersebut terjadi, sangat dimungkinkan karena orang yang bepergian tersebut berada pada kondisi ekonomi yang lemah, artinya bepergian atau tidak bepergian kondisinya memang sudah sangat lemah secara ekonomi. Pendekatan banyak dilakukan oleh sejumlah lembaga pengumpul zakat mengategorikan para perantau yang mengalami kegagalan dalam mengais rezeki di kota atau para pelajar yang merantau di kota lain untuk menuntut ilmu dikategorikan sebagai ibnu sabil.

${ }^{15}$ MA. Sahal Mahfudh, Nuansa Fiqh Sosial (Yogyakarta: LKiS, 2011), hal. 153 


\section{E. Membangun Basis Data Musakki}

Agar dapat membangun basis data muzaki, terlebih dahulu perludiketahui siapa muzaki dan siapa mustahik. Yang digunakan oleh BAZNAS dan kebanyakan OPZ di Indonesia, dalam membedakan antara muzaki dan mustahik, biasanya dikenal sebagai garis kemiskinan, adalah nisab zakat pertanian, yaitu nisab zakat beras senilai $524 \mathrm{~kg}$. Jika asumsi harga beras standar adalah Rp. 6000/kg, maka nisabnya menjadi Rp. 3,144 juta/bulan. Artinya, sebuah rumah tangga disebut miskin jika pendapatannya Rp. 3,144 juta/bulan, atau jika dihitung perkapita, Rp. 806,2 ribu/bulan, dan jika dihitung perhari, Rp. 26.873/hari. Dasar pertimbangan digunakannya nisab zakat pertanian adalah unsur keadilan, dimana seorang petani apabila menghasilkan panen lebih dari $524 \mathrm{~kg}$ beras akan terkena kewajiban zakat. ${ }^{16}$

Langkah berikutnya adalah melakukan upaya intensifikasi dan ekstensifikasi. Langkah intensifikasi zakat dan membangun basis data muzaki dapat dilakukan melalui kegiatan sebagai berikut: ${ }^{17}$

1. Mapping muzaki; bertujuan untuk mendapatkan gambaran umum potensi zakat di suatu wilayah, yang digunakan sebagai petunjuk untuk memformulasikan strategi peningkatan penerimaan zakat yang tepat. Salah satu tujuan terpenting di sini adalah mendapatkan data-base wajib zakat (muzaki) potensial. Secara empiris, kecenderungan distribusi pendapatan di Indonesia adalah sangat tidak merata. Maka, mendapatkan muzaki potensial (high net wealth zakat-payers), walau hanya sedikit jumlahnya, akan mampu meningkatkan penerimaan zakat secara signifikan. Sebagai misal, jika organisasi pengelola zakat (OPZ) mampu mendapatkan daftar 100 atau

\footnotetext{
${ }^{16}$ Kasri, Rahmatina A dan Arif R. Haryono (Ed), Bangsa Betah Miskin: Kajian Kritis atas Indikator dan Program Pengentasan Kemiskinan di Indonesia, Sebuah Tawaran Solusi, (Jakarta: IMZ,bn2011), hlm. 9

${ }^{17}$ Nana Minarti, dkk (Ed), Indonesia Zakat..., hlm. 170-171.
} 
1000 muslim terkaya baik di tingkat nasional maupun lokal, data ini akan menjadi terobosan penting dalam perbaikan strategi peningkatan penerimaan zakat. Kerjasama dengan otoritas pajak, otoritas perbankan, BKKBN (Badan Koordinasi Keluarga Berencana Nasional), BPS, dan dinas ketenagakerjaan menjadi sangat penting dan krusial bagi OPZ disini.

2. Profiling muzaki; bertujuan menyajikan informasi muzaki secara individual, mengikuti perkembangan pembayaran zakat-nya dari waktu ke waktu, mengenal kondisi usaha dan ekonomi muzaki, serta memberikan pelayanan yang tepat sesuai dengan karakternya. Isu krusial disini adalah bagaimana mendapatkan informasi

muzaki secara komprehensif namun murah. Langkah paling efektif dan efesien adalah dengan mendayagunakan data pihak ketiga, misal data dirjen pajak. Setelah mengetahui informasi ini, BAZNAS dapat menetapkan pelayanan zakat yang sesuaiyang dapat direkomendasikan ke OPZ. Hal ini bisa disebut sebagai Langkah pendalaman dari metode sistem keanggotaan di OPZ yang memiliki tujuan sama, yaitu membentuk donor society. Perlakuan yang customized ini sangat relevan untuk kasus muzaki potensial. Upaya yang dapat dilakukan disini antara lain membuka call center yang didukung oleh "knowledge base” yang baku, help desk di setiap konter OPZ potensial dengan staf khusus yang terlatih.

3. Benchmarking; bertujuan untuk menetapkan satu besaran pembayaran zakat yang wajar dan terbaik oleh muzaki di kelompok pendapatan atau karakteristik tertentu, yang kemudian dijadikan sebagai ukuran standar. Upaya ini akan memastikan bahwa muzaki membayar zakat secara benar dan sesuai dengan ketentuan syariah.

Sementara langkah ekstensifikasi, yang merupakan langkah perluasan basis zakat, secara umum dapat dibagi dalam dua kategori: ${ }^{18}$

Pertama, upaya untuk menambah jumlah muzaki yang menunaikan kewajiban zakat melaui OPZ. Upaya terpenting disini adalah memberikan penyadaran bagi

${ }^{18}$ Ibid., hlm. 171 
muzaki untuk menunaikan kewajibannya ke lembaga melalui kegiatan promosi, sosialisasi dan edukasi yang masif. Hingga kini, upaya terbesar masih terkonsentrasi di kegiatan promosi dan sosialisasi. Langkah ini ke depan perlu semakin diperkuat dengan memperbaiki strategi komunikasi OPZ melalui riset pasar, penggunaan seluruh kanal informasi yang memungkinkan, beralih dari advertising ke public relation dan publicity, serta mendorong public education secara luas melalui kemitraan dengan ormas Islam, masjid pesantren, lembaga pendidikan, hingga parpol Islam.

Secara umum, penambahan jumlah muzaki dapat dilakukan melaui tiga pendekatan, yaitu:

1) pendekatan berbasis pemberi kerja dan bendaharawan pemerintah dengan sasaran antara lain karyawan, PNS dan pejabat negara;

2) pendekatan berbasis properti, dengan sasaran orang pribadi atau perusahaan yang melakukan atau memiliki usaha di pusat perdagangan dan pusat perkantoran; dan

3) pendekatan berbasis profesi, dengan sasaran profesi yang telah memiliki asosiasi yang mapan seperit dokter, pengacara dan notaris. BAZNAS harus memfasilitasi OPZ untuk hal ini dengan melakukan pendekatan dan kerjasama dengan pihak otoritas terkait.

Di tingkat lokal, upaya penghimpunan dana zakat dapat ditingkatkan secara signifikan melalui pendekatan kultural. Di banyak daerah, pendekatan kulturalemosional lebih kuat berperan dibandingkan pendekatan legal-formal-rasional. Upaya pendekatan kultural perlu dilakukan OPZ terhadap basis massa riil di tingkat akar rumput seperti pesantren, majelis taklim dan masjid. Dengan demikian, diharapkan akan terjadi zakat-switching di masyarakat lokal dari yang semula zakat dikelola secara personal-tradisional menjadi dikelola amil profesional.

Kedua, ekstensifikasi zakat juga dapat dilakukan melalui upaya mengoptimalkan basis zakat dari jenis-jenis zakat yang potensial. Basis zakat selama ini masih didominasi oleh zakat fithrah dan zakat profesi, dapat 
ditingkatkan secara signifikan dengan menggali potensi beberapa jenis zakat potensial, antara lain adalah zakat perusahaan.

\section{F. Komitmen Perusahaan Menjadi Muzakki}

Mengenai proses regulasi pengelolaan zakat hingga zakat mengurangi pembayaran pajak (dalam hal ini pajak penghasilan), hal ini sudah diatur sejak adanya UU No. 38 Tahun 1999 tentang Pengelolaan Zakat, dan kemudian lebih dipertegas oleh UU Zakat yang terbaru yang menggantikan. ${ }^{19}$ Undang-undang 38/1999 yaitu UU No. 23 Tahun 2011 tentang Pengelolaan Zakat. Latar belakang dari pengurangan ini dijelaskan dalam penjelasan Pasal 14 ayat (3) UU 38/1999 bahwa pengurangan zakat dari laba/pendapatan sisa kena pajak adalah dimaksudkan agar wajib pajak tidak terkena beban ganda, yakni kewajiban membayar zakat dan pajak. Ketentuan ini masih diatur dalam UU yang terbaru yakni dalam Pasal 22 UU 23/2011 "Zakat yang dibayarkan oleh muzaki kepada BAZNAS atau LAZ dikurangkan dari penghasilan kena pajak" Pergulatan pemikiran hukum ekonomi Islam di Indonesia, integrasi zakat dan pajak merupakan perbincangan baru yang selama satu dekade terakhir menjadi lebih sering diperbincangkan dan dibahas baik dalam kacamata hukum positif maupun hukum Islam. Perdebatan paling krusial terletak pada dasar pengelolaan zakat dan pajak yang dianggap memiliki unsur-unsur yang berbeda dengan pajak. Beberapa ulama yang mengeluarkan ijtihad syar'inya terkait dengan integrasi zakat dan pajak antara lain Masdar Farid Mas'udi, Didin Hafiddudin, dan MUI Pemegang saham merupakan bagian dari pemilik perusahaan yang mewakilkan operasionalnya kepada pihak manajemen untuk menjalankan operasional perusahaan dimana keutungan dan kerugian perusahaan ditanggung bersama oleh pemegang saham. ${ }^{20}$ Keuntungan dan kerugian perusahaan dapat

\footnotetext{
${ }^{19}$ Wahid, M. A. R. Integrasi Pajak Dan Zakat Di Indonesia. ISLAMICONOMIC: Jurnal Ekonomi Islam, 8(1), 27-58. 2018.

${ }^{20}$ Pertiwi, H. I., \& Laily, S. N. (2018). Konsep, Aplikasi, Dan Perilaku Akuntansi Terhadap Zakat Aset Pada Perusahaan Dagang ( Studi Pada Toko Emas Gajah Di Sidoarjo. T.th.
} 
diketahui pada waktu Rapat Umum Pemegang Saham (RUPS) dan pada saat itulah zakat di wajibkan. Namun para ulama berbeda tentang kewajiban pengeluaran zakatnya.

Perusahaan sebagai wajib zakat (muzakki) juga telah di fatwakan oleh MUI sejak tahun 2004.tetapi nampaknya belum berpengaruh signifikan terhadap kemauan dan komitmen perusahaan untuk menjadi muzakki. Analisis penulis, sejumlah tantangan yang dihadapi perusahaan untuk menjadi muzakki antara lain; Pertama, Tidak ada sanksi bagi pelanggar. ${ }^{21}$ Adanya fatwa dan bahkan keberadaan UU yang mengatur zakat belum mampu memberikan sanksi administrasi sekalipun apalagi pidana bagi pelanggarnya. Para wajib zakat yang tidak membayar zakat tidak bisa dikenakan sanksi berdasarkan UU maupun peraturan lain termasuk fatwa. Padahal UU semestinya dapat berfungsi demikian. BAZNAS sebagai Lembaga yang diberikan kewenangan untuk mengatur dan mengelola serta mengawasi zakat oleh UU bukan merupakan lembaga Negara yang berhak memberikan sanksi administrasi bagi wajib zakat (individu dan badan usaha) yang tidak melaksanakan zakatnya. Berbeda dengan kewenangan Ditjend Pajak Kemenkeu. Oleh karena itu, UU yang mengatur zakat juga mengatur sanksi administrasi dan kewenangan lembaga yang mengatur dan atau mengelola zakat setingkat lembaga Negara yang berwenang memberikan sanksi;

Kedua, Perusahaan dihadapkan pada potensi pembayaran ganda dengan pajak (double payment). Sebelum ada aturan yang jelas dan legal yang bersifat mengikat antara zakat perusahaan dan pajak perusahaan (pajak penghasilan badan usaha), maka perusahaan akan menunda atau tidak membayar zakat perusahaan. Apalagi bagi perusahaan yang mengelola sumber daya alam, berdasarkan UU Perseroan Terbatas, mereka diwajibkan untuk membayar tanggung jawab social perusahaan terhadap lingkungan. Sehingga apabila kewajiban zakat perusahaan diterapkan mereka berpotensi triple payment yaitu

\footnotetext{
${ }^{21}$ AlimNd
} 
beban pajak, tanggung jawab social, dan zakat; perusahaan akan menunda atau tidak membayar zakat perusahaan. Apalagi bagi perusahaan yang mengelola sumber daya alam, berdasarkan UU Perseroan Terbatas, mereka diwajibkan untuk membayar tanggung jawab social perusahaan terhadap lingkungan. Sehingga apabila kewajiban zakat perusahaan diterapkan mereka berpotensi triple payment yaitu beban pajak, tanggung jawab social, dan zakat;

Ketiga, Potensi khlafiyah wajib zakat perusahaan sebagai muzaki. Syarat wajib zakat diantaranya adalah beragama Islam. Perusahaan sebagai badan usaha yang dikelola perorangan identic dengan wajib zakat perorangan karena keuntungan perusahaan adalah milik perorangan. Sementara itu, perusahaan sebagai badan usaha yang dimiliki banyak orang (pemodal) yang berbeda agama serta kemungkinan kepemilikannya (saham) tidak hanya oleh perorangan tetapi juga institusi maka keuntungan perusahaan bukan milik orang-perorang. Celah dari kondisi ini dapat menjadi rasionalisasi perusahaan tidak termasuk muzaki;

Keempat, Metode dan basis penghitungan zakat juga menjadi perdebatan. Setidaknya PMA di atas dapat digunakan referensi dan atau pedoman. Perbedaan metode penghitungan juga berimplikasi terhadap perlakuan akuntansi. Di beberapa Negara yang telah disebutkan di atas juga telah diantisipasi dengan diberlakukannya standar akuntansi untuk perlakuan akuntansi zakat perusahaan. Sementara itu, di Indonesia juga telah diterbitkan standar akuntansi untuk zakat bahkan telah ada tiga standar akuntansi yang mengatur tentang akuntansi zakat tetapi ketiganya belum mengatur akuntansi zakat perusahaan khususnya bagi perusahaan yang menjadi muzaki zakat perusahaan.

Faktor tingkat pemahaman agama juga menjadi tolak ukur keengganan menjadi muzakki, seharusnya semakin baik pemahaman agama seseorangmembuat ia semakin termotivasi untuk menunaikan zakat. ${ }^{22}$ Karena ia sudah mengerti bahwa membayar zakat adalah sebuah kewajiban, ia mengetahui balasan- balasan kebaikan yang akan dia dapatkan jika membayar zakat, dan

\footnotetext{
${ }^{22}$ Hadi, A. C. Corporate Social Responsibility dan Zakat Perusahaan dalam PerspektifHukum Ekonomi Islam. AHKAM Jurnal Ilmu Syariah, 16(2), 229-240. 2016.
} 
mengetahui hukuman-hukuman bagi mereka yang tidak mau membayar zakat padahal mereka mampu. Perusahaan (Hadi, 2016) dihadapakan pada kewajiban CSR dan Zakat, keduanya memiliki kewajiban yang sama terhadap aturan negara. Namun beda dari segi kewajiban agama. CSR adalah pertanggungjawaban sosial sedangkan zakat pertanggungjawaban terhadap Allah. Jika perusahaan membayar keduanya maka akan berpengaruh terhadap pendapatan.

Perusahaan mengeluarkan zakat secara mandiri bukan melalui badan amil zakat (BAZ) atau lembaga amil zakat (LAZ) resmi, sehingga tidak tercatat dan terlapor secara resmi bahwa perusahaan tersebut telah mengeluarkan zakat. Seperti pemahaman umum masyarakat, bahwa mengelaurkan zakat itu tidak harus melalui BAZ atau LAZ tapi bisa dilakukan sendiri secara kepada mustahik yang terpenting tepat sasaran. Demikian juga dengan perusahaan, banyak memilih untuk menyalurkan secara langsung zakat perusahaan kepada mustahik baik dalam bentuk program produktif atau konsumtif. Berdasarakan hasil penelitian Yusuf Wibisindo, menyimpulkan bahwa, argumentasi yang melandasi UU No. 23/2011 di Indonesia tentang otoritas pengelolaan zakat hanya pemerintah semata yang diklaim bersumber dari al-Qur'an dan hadits serta pemikiran dunia Islam klasik hingga kontemporer. 


\section{BAB III \\ PENUTUP}

\section{A. Kesimpulan}

Dari uraian di atas, dapat diketahui bagaimana tahapan zakat diwajibkan dan bagaimana ketentuan yang telah ditetapkan oleh mengenai muzakki dan juga mustahiq. Menurut Undang-Undang No. 38 Tahun 1999 tentang Pengelolaan Zakat pasal 1, muzakki adalah orang atau badan yang dimiliki oleh orang muslim yang berkewajiban menunaikan zakat. Zakat diwajibkan atas orang yang telah memenuhi syarat-syarat, yaitu: Islam, merdeka, baligh dan berakal sehat, memiliki harta atau kekayaan yang cukup nisab, memiliki harta atau kekayaan yang sudah memenuhi haul, memiliki harta secara sempurna dan muzakki adalah orang yang berkecukupan atau kaya.

Mustahiq adalah orang atau badan yang berhak menerima zakat. Para fuqaha menetapkan lima syarat atas orang yang berhak menerima zakat yaitu: kefakiran atau kekurangan pemenuhan kebutuhannya, penerima zakat harus muslim, penerima zakat bukan berasal dari keturunan Bani Hasyim, penerima zakat bukan orang yang lazim diberi nafkah, dan penerima zakat akil dan baligh.

Allah SWT telah menentukan golongan-golongan tertentu yang berhak menerima zakat, dan bukan diserahkan kepada pemerintah untuk membagikannya sesuai kehendaknya. Oleh karena itu, zakat harus dibagikan kepada golongangolongan yang telah ditentukan yakni seperti dalam surat at-Taubah ayat 60 yaitu fakir, miskin, amil zakat, muallaf, riqab, gharim, fi sabilillah dan ibnu sabil. Di mana pembahasan kedelapan golongan ini masih mengalami perkembangan sejalan dengan semakin kompleksnya kehidupan sosial yang ada sehingga para ahli fikih dan ulama kerap melakukan diskusi yang berkaitan dengan hal ini, tidak terkecuali di Indonesia. Sehingga menciptakan indikator dan kriteria dari tiap golongan tersebut untuk diselaraskan dengan kondisi di Indonesia yang pada akhirnya digunakan untuk membantu pemerintah dalam pengelolaan dan pendistribusian zakat tersebut. 


\section{DAFTAR PUSTAKA}

Abidin, Slamet dan Suyono. 1998. Fiqih Ibadah. Bandung: Pustaka Setia.

Al-Zuhayly, Wahbah. 2008. Zakat: Kajian Berbagai Mazhab. Bandung: PT Remaja Rosdakarya. Ekonomi Umat.Malang: UIN-Maliki Press.

Khasanah, Umrotul. 2010. Manajemen Zakat Modern: Instrumen Pemberdayaan

Mahfudh, MA. Sahal. 2011. Nuansa Fiqh Sosial. Yogyakarta: LKiS.

Majelis Ulama Indonesia. 2011. Himpunan Fatwa MUI Sejak 1975. Jakarta: Erlangga

Mufraini, M. Arif. 2006. Akuntansi dan Manajemen Zakat. Jakarta: Kencana.

Qardhawi, Yusuf. 1995. Problematika Islam Masa Kini: Qardhawi

Menjawab. Bandung: Trigenda Karya.

Ritonga, Rahman dan Zainuddin.2002. Fiqh Ibadah.Jakarta: Gaya Media Pratama.

Samsul SAB MA, Komitmen Perusahaan Menjadi Muzakki

Sitanggal, Anshory Umar. 1987. Fiqh Syafi'i Sistimatis II.Semarang:

CV. Asy-Syifa'.

Kementerian Agama, "UU No. 38 Tahun 1999 tentang Pengelolaan Zakat", http://kemenag.go.id, diakses pada Sabtu, 12 September 2015, 12:23 WIB

Trisno Wardy Putra Konsep Manajemen Pengumpulan Dana Zakat 
